\title{
THE EFFECTS OF THE DURATION OF COLD MACERATION ON THE COMPOSITION AND SENSORY PROPERTIES OF SMEDEREVKA WINES
}

\author{
Sonja N. Jordeva ${ }^{1 *}$, Kiro D. Mojsov ${ }^{1}$, Darko Andronikov ${ }^{1}$, Aco Janevski $^{1}$, Stevan Gaber ${ }^{2}$
}

${ }^{1}$ Faculty of Technology, University "Goce Delčev" Štip, Republic of Macedonia

2Faculty of Economics, University "Goce Delčev" Štip, Republic of Macedonia

(ORIGINAL SCIENTIFIC PAPER)

UDC 663.2:66.063.4

Although the composition of the grapes depends on its variety, the soil and climatic conditions, there is little variation in the actual cell structure of the plant. The control of maceration or skin contact conditions is vital for obtaining high quality white wines. In practice, a classical the maceration at the temperature of $20-25{ }^{\circ} \mathrm{C}$ and a cold maceration at $5-10{ }^{\circ} \mathrm{C}$ are commonly used. The aim of this work was to investigate the changes in the composition and sensory properties of Smederevka wines obtained with different cold skin contact times at $8^{\circ} \mathrm{C}$, during 12 and 24 hours. A chemical analysis wines includes basic chemical compounds, organic acids, total phenols and higher alcohols. A sensory analysis of the wines by 100 points method was carried out. The results showed a significant increase in the dry extract, ash, total phenol and a decrease in tartaric acid and a higher alcohol content in Smederevka wines obtained by 12 or 24 hours cold maceration period. These results indicate that cold maceration positively influences the quality of Smederevka wines. The best organoleptic quality of Smederevka wines was obtained by cold maceration at $8^{\circ} \mathrm{C}$ during 24 hours.

\section{Introduction}

Smederevka is a variety of white grapes cultivated in the Republic of Macedonia used for the production of high quality white table wines. Wines and grapes contain a number of polyphenolic constituents that play a mayor role in enology. White wines contain mainly phenolic acids and flavanols [1]. Polyphenolic compounds are very important constituents that contribute to the colour, taste, and feel of wines. The wine aroma is one of its most important characteristics produced from different chemical classes of volatile compounds belonging to higher alcohols, esters, aldehydes, lactones, terpenes, volatile phenols, fatty acids, carbonyls, sulphur and nitrogen compounds. Their concentration in the wine depends on the grapes variety, a light intensity, the soil, the climate, the temperature, a degree of maturation, maceration, a yeast strain, the addition of enzyme preparations, the fermentation temperature etc. [2,3].

Maceration or skin contact is a very important phase in the production of wines. The control of the skin contact conditions is vital for obtaining high quality white wines. In this sense, maceration has been widely investigated and it has even become a standard procedure in many wine-production areas [4]. Classic maceration can increase the extraction of phenolic compounds connected with the increase of wine astringency and bitterness, and cold maceration leads to the increased extraction of aromatic compounds from berry skin while the extraction of phenolic compounds is reduced [5]. Lateyron [6] examined differences in Chardonnay must and the wine produced by following the skin contact for 6 hours at $15,5^{\circ} \mathrm{C}, 20^{\circ} \mathrm{C}$ and $24^{\circ} \mathrm{C}$. She found lower acidity, higher $\mathrm{pH}$, higher total nitrogen, higher phenolic compounds and deeper color with the increased skin contact temperature. Ramey et al. [7] researched differences in Chardonnay must and wines produced following the skin contact for 20-25 hours at $9^{\circ} \mathrm{C}, 15^{\circ} \mathrm{C}, 19,5^{\circ} \mathrm{C}$ and $27^{\circ} \mathrm{C}$. A significant positive correlation exists between the skin contact temperatures and both flavonoid and total phenols in must and wines. The higher flavonoid levels produced by the warm skin contact resulted in wines which were more deeply colored, had a greater capacity for browning and a more coarse character than the wines produced with the cooler skin contact. The temperature control in the $10{ }^{\circ} \mathrm{C}$ range was extremely effective in limiting the flavonoid extraction. Volatile components showed mixed behavior. Some compounds increased in the concentration with temperature, while others decreased. The skin contact at different temperatures did not affect all classes of compounds similarly. Higher phenolic levels provided by warm holding temperatures were not accompanied

\footnotetext{
*Author address: Sonja N. Jordeva, Faculty of Technology, University "Goce Delčev" Štip, Krste Misirkov No. 10-A, P.O.Box 201, 2000 Štip, Republic of Macedonia

E-mail: sonja.jordeva@ugd.edu.mk

The manuscript received: August, 20, 2016.

Paper accepted: November, 18, 2016
} 
by uniformly higher concentrations of volatile phenols in either must or wine.

The aim of this work was to investigate the changes in the wine composition and sensory properties of the Smederevka wine obtained with different cold skin contact times at the temperature of $8{ }^{\circ} \mathrm{C}$.

\section{Experimental}

\section{Grape samples}

White wine grapes from Smederevka variety, Vitis vinifera L., cultivated at the Ovce pole vineyard, the Povardarie wine region, the Republic of Macedonia, were harvested during the 2013 season at optimal maturity (180-190 g/l sugar). The grapes were harvested early in the morning and placed into $20 \mathrm{~kg}$ boxes.

\section{Wine samples}

Harvested Smederevka grapes $(300 \mathrm{~kg})$ were transported to the wine cellar of IMACO Winery, Stip, the Republic of Macedonia. The grapes were processed by using a crusher/destemmer and divided into 3 lots (100 kg for each lot) and collected in 150 liters plastic fermentation tanks. The must obtained by the separation of the liquid fraction from solid cluster parts right after grapes crashing, without maceration, was used as the first control treatment. The second treatment was cold maceration at $8{ }^{\circ} \mathrm{C}$ in duration of 12 hours and the third treatment was cold maceration at $8{ }^{\circ} \mathrm{C}$ in duration of 24 hours. All treatments were performed under controlled temperature conditions of $8^{\circ} \mathrm{C}$. Each of the mentioned treatments was performed in three repetitions. The must from the control treatment was treated with $60 \mathrm{mg} / \mathrm{l} \mathrm{SO}_{2}$ (added in the form of $5 \%$ sulfurous acid) and the sediment for 24 hours at $8{ }^{\circ} \mathrm{C}$. Grape mashes cold maceration treatments were treated with $60 \mathrm{mg} / / \mathrm{SO}_{2}$ after the maceration process finished (before pressing). Alcoholic fermentation of all treatments was performed under controlled temperature conditions at $17^{\circ} \mathrm{C}$ with the addition of the selected wine yeast NEUTRE SC, Saccharomyces cerevisiae $(20 \mathrm{~g} / \mathrm{hl})$, supplied from Lallemand (Canada) and plunged twice a day until the completion of fermentation. All wines were decanted and treated with $30 \mathrm{mg} / \mathrm{l}$ $\mathrm{SO}_{2}$ before bottling.

\section{Chemical analyses and sensory evaluation}

The wine samples of all treatments were chemically analyzed just after decanting and three months later tested by sensory evaluation. The chemical analyses of the basic wine components were analyzed by O.I.V. Official methods [8]. Total phenols were determined spectrophotometrically by using Agilent 8453 UV-VIS spectrophotometer at $280 \mathrm{~nm}$ (wavelength) with Folin-Ciocalteu reagent (from Merck, Germany) following the method of Slinkard and Singleton [9]. Organic acids were determined by HPLC method [10]. The sensory evaluation of each wine was obtained by the 100-point O.I.V. method, with a panel of eight judges. Least Significant Difference
(LSD) comparison test was used to statistically interpret mean differences in mean values if any, at the $95 \%$ accuracy level.

\section{Results and discussion}

The chemical composition of Smederevka musts and wines obtained with different cold maceration times from the Smederevka cultivar is given in Tables 1, 2.

Table 1. Chemical composition of the Smederevka must

\begin{tabular}{lccc}
\hline Parameters & \multicolumn{3}{c}{ Smederevka must samples } \\
& Control treatment & $\begin{array}{c}\text { Cold maceration } \\
\mathbf{8}^{\circ} \mathbf{C} / \mathbf{1 2} \text { hours }\end{array}$ & $\begin{array}{c}\text { Cold maceration } \\
\mathbf{8}^{\circ} \mathbf{C} / \mathbf{2 4} \text { hours }\end{array}$ \\
\hline Sugar, g/l & 188.5 & 185.5 & 185.5 \\
Total acidity, g//* & 6.7 & 6.4 & 6.4 \\
$\mathrm{pH}$ & 3.1 & 3.2 & 3.2 \\
${ }^{*}$ as tartaric acid & & &
\end{tabular}

Table 2. Mean values of the basic chemical composition and total phenols concentrations of Smederevka wines

\begin{tabular}{lcccc}
\hline Compounds & $\begin{array}{c}\text { Control } \\
\text { treatment }\end{array}$ & $\begin{array}{c}\text { Smederevka wine samples } \\
\text { Cold maceration } \\
\mathbf{8}^{\circ} \mathbf{C} / \mathbf{1 2} \text { hours }\end{array}$ & $\begin{array}{c}\text { Cold maceration } \\
\mathbf{8}^{\circ} \mathbf{C} / \mathbf{2 4} \text { hours }\end{array}$ & LSD \\
\hline Alcohol, vol\% & 12.5 & 12.4 & 12.4 & n.s. \\
Residual sugar, g/l & 1.6 & 2.0 & 2.0 & n.s. \\
Dry extract, g/l & $17.4 \mathrm{a}$ & $19.6 \mathrm{~b}$ & $20.2 \mathrm{c}$ & $5 \%$ \\
Total acidity, g/ $\mathbf{l}^{*}$ & $5.4 \mathrm{a}$ & $5.2 \mathrm{~b}$ & $5.2 \mathrm{~b}$ & $5 \%$ \\
Tartaric acid, g/l & $2.3 \mathrm{a}$ & $1.8 \mathrm{~b}$ & $1.7 \mathrm{~b}$ & $5 \%$ \\
Malic acid, g/l & 2.4 & 2.3 & 2.3 & n.s. \\
Citric acid, g/l & 0.25 & 0.27 & 0.27 & n.s. \\
Lactic acid, g/l & 0.15 & 0.15 & 0.15 & n.s. \\
Succinic acid, g/l & 0.5 & 0.5 & 0.5 & n.s. \\
Volatile acidity, & 0.35 & 0.38 & 0.37 & n.s. \\
g// & & & & \\
pH & 3.2 & 3.3 & 3.3 & n.s. \\
Ash, g/l & $1.9 \mathrm{a}$ & $2.1 \mathrm{~b}$ & $2.2 \mathrm{~b}$ & $5 \%$ \\
Total phenols, mg/l & $235.4 \mathrm{a}$ & $262.3 \mathrm{~b}$ & $312.6 \mathrm{c}$ & $5 \%$ \\
\hline Different letters beside the & mean of a compound denote a significant difference among treatments
\end{tabular}

(a,b,c for $5 \%$ ); n.s.-not significant; *as tartaric acid; **as acetic acid

The results show that cold maceration resulted in the decrease of total acidity and the increase in $\mathrm{pH}$ values in both must and wines. These results are in accordance with Herjavec and Majdak [11]. According to RibéreauGayon et al. [12] and numerous other authors, these changes are linked to the liberation of potassium from the skins and the resulting partial salification of tartaric acid. This is also confirmed in our study where the results presented in Table 2 show that only the tartaric acid concentration in both cold maceration treatments was significantly lower compared to the control treatment. Cold maceration time had no significant effect on the succinic acid concentration. Succinic acid in obtained wines is present in the quantity of $0.5 \mathrm{~g} / \mathrm{l}$ and gives a special taste. The phenolic compounds in the wine originate from the seed, skin and stems, and only a small part is produced as a yeasts metabolism product. Consequently, skin maceration can significantly influence the final total phenol concentration in obtained wines. The results presented in Table 2 show that total phenol concentrations in wines obtained by cold maceration increase proportionally to the maceration time, compared to the control wine. These results are in accordance with Jackson [13]. A significant increase in the dry extract and ash concentrations in both cold maceration treatment wines was noted compared to the control wine. Ash amounts were 
increased with a longer maceration period which is due to the extraction of minerals in the maceration process [12]. Cold maceration time had no significant effect on the ethanol concentration, volatile acidity, $\mathrm{pH}$ and residual sugar.

Higher alcohol data are given in Table 3.

Table 3. Mean values of higher alcohols, acetaldehyde and ethyl acetate concentrations of Smederevka wines

\begin{tabular}{lcccc}
\hline Compounds, mg/l & $\begin{array}{c}\text { Control } \\
\text { treatment }\end{array}$ & $\begin{array}{c}\text { Smederevka wine samples } \\
\text { Cold maceration } \\
\mathbf{8}^{\circ} \mathbf{C} / \mathbf{1 2} \text { hours }\end{array}$ & $\begin{array}{c}\text { Cold } \\
\text { maceration } \\
\mathbf{8}{ }^{\circ} \mathbf{C} / \mathbf{2 4} \text { hours }\end{array}$ & LSD \\
\hline Methanol & $65.6 \mathrm{a}$ & $92.3 \mathrm{~b}$ & $124.2 \mathrm{c}$ & $5 \%$ \\
1- Propanol & 18.8 & 19.4 & 19.1 & n.s. \\
2-methyl propanol & $45.2 \mathrm{a}$ & $45.5 \mathrm{a}$ & $28.6 \mathrm{~b}$ & $5 \%$ \\
2-methyl butanol & $43.6 \mathrm{a}$ & $35.3 \mathrm{~b}$ & $22.8 \mathrm{c}$ & $5 \%$ \\
3-methyl butanol & $209.4 \mathrm{a}$ & $161.2 \mathrm{~b}$ & $111.4 \mathrm{c}$ & $5 \%$ \\
¿ Higher alcohol & 382.6 & 353.7 & 306.1 & n.s. \\
Acetaldehyde & 105.6 & 101.8 & 103.2 & n.s. \\
Ethyl acetate & 59.6 & 60.8 & 62.1 & \\
\hline
\end{tabular}

Different letters beside the mean of a compound denote a significant difference among treatments (a,b,c for $5 \%$ ); n.s.-not significant

According to Jackson [13], a higher alcohol concentration below $300 \mathrm{mg} / \mathrm{L}$ contribute to a desirable aroma complexity of the wine, but when these concentrations exceed $400 \mathrm{mg} / \mathrm{L}$, these compounds are regarded as a negative quality factor. The results presented in Table 3 show that all tested wines had a relatively high concentration of total higher alcohols, but also there was a significant difference between them. Cold maceration at $8^{\circ} \mathrm{C}$ for 24 hours contained the significantly lowest amount of total higher alcohols compared to other treatments. The wines made from the skin maceration must also had higher concentrations of methanol than control wines, which is in accordance with Palomo et al. [14]. Methanol is derived from demethylation of skin pectins. Cold maceration had no effect on the concentration of acetaldehyde, which is in accordance with Selli et al. [15]. Esters are one of the major components of the wine aroma. The ethyl acetate concentration in all tested wines was very low and there were no significant differences noted.

The sensory evaluation of Smederevka wines was conducted by eight panelists and 100-points O.I.V. method (Table 4).

Table 4. Average results of the sensory evaluation of Smederevka wines by the 100-points O.I.V. method

\begin{tabular}{lccc}
\hline & \multicolumn{3}{c}{ Smederevka wine samples } \\
Control treatment & $\begin{array}{c}\text { Cold maceration } \\
\mathbf{8}^{\circ} \mathbf{C} / \mathbf{1 2} \text { hours }\end{array}$ & $\begin{array}{c}\text { Cold } \\
\text { maceration } \\
\mathbf{8}^{\circ} \mathbf{C} / \mathbf{2 4} \text { hours }\end{array}$ \\
\hline Total score & 81.2 & 82.4 & 84.6 \\
\hline
\end{tabular}

The results showed that a prolonged cold maceration time had a positive influence on the Smederevka wines quality, and the wines obtained by cold maceration at $8{ }^{\circ} \mathrm{C}$ during the 24 hour time period (84.6 points) had the significantly best general quality. These wines were characterized by varietal flavors, with ripe fruit and the complexity of the taste. This is probably connected with the increased mouthfeel, likely due to the increased phenol and the lower amount of higher alcohols. The wines obtained by cold maceration at $8{ }^{\circ} \mathrm{C}$ during the 12 hour time period (82.4 points) had lower evaluation. The wines obtained without maceration (81.2 points) had the lowest evaluation.

\section{Conclusion}

The cold maceration treatment period of 12 or 24 hours positively affects the quality of Smederevka wines, and gives wines with a significant increase in the dry extract, ash and total phenols and a decrease in tartaric acid and higher alcohols. According to the results of our study, we can conclude that the best organoleptic quality of Smederevka wines was obtained by cold maceration at $8{ }^{\circ} \mathrm{C}$ during the 24 hour time period.

\section{References}

[1] P. Ribéreau-Gayon, Y. Glories, A. Maujean, D. Dubourdieu. Handbook of Enology,Volume 2, The Chemistry of Wine: Stabilization and Treatments, England, John Wiley\&Sons Ltd., 2000, 141-205.

[2] P. A. Skinkis, B. P. Bordelon, E. M. Butz, Effects of sunlight exposure on berry and wine monoterpenes and sensory characteristics of traminette, American Journal of Enology and Viticulture, 61 (2010) 147-156.

[3] S. Bureau, A. Razungles, R. Baumes, The aroma of Muscat of Frontignan grapes: effect of the light environment of vine or bunch on volatiles and glycoconjugates, Journal of the Science of Food and Agriculture, 80 (2000) 20122020.

[4] R. S. Jackson. Wine Science Principles, Practice, Perception, 4th edition., San Diego, Academic press, 2014, p. 978.

[5] T. De Rosa. Technologia dei vini bianchi, Brescia, Edizione Aeb, 1999.

[6] C. Lateyron. Vinification et etude de la maceration des mouts blancs dans une cave Californienne, Dissertation, Institut of Enology, University of Bordeaux II, 1983.

[7] D. Ramey, A. Bertrand, S. C. Ough, V. L. Singleton, E. Sanders, Effect of skin contact temperature on Chardonnay musts and wine composition, American Journal of Enology and Viticulture, 37 (1986) 99-106.

[8] O.I.V., International Code of Oenological Practices, Paris, 2001

[9] K. Slinkard, V. L. Singleton, Total phenol analyses: automation and comparison with manual methods, American Journal of Enology and Viticulture, 28 (1977) 49-55.

[10] A. Zotou, Z. Loukou, O. Karava, Method Development for the Determination of Seven Organic Acids in Wines by Reversed-Phase High Performance Liquid Chromatography, Chromatographia, 60 (2004) 39-44.

[11] S. Herjavec, A. Majdak, The Influence of maceration on the composition of some volatile compounds and sensory properties of Traminer wines, Agriculturae Conspectus Scientificus, 67 (2002) 11-18.

[12] P. Ribéreau-Gayon, D. Dubourdieu, B. Donéche, A. Lonvaud. Handbook of Enology, Volume 1, The Microbiology of Wine and Vinifications, New York, John Wiley\&Sons, 2000. 
[13] R. S. Jackson. Wine science: Principles and Applications, New York, Academic press, 2000.

[14] E. S. Palomo, M. C. Gonzales-Vinas, M. C. Diaz- Maroto, A. Soriano-Perez, M. S. Perez-Cowllo, Aroma potential of Albillo wines and effect of skin contact treatment, Food Chemistry, 103 (2007) 631-640.
[15] S. Selli, A. Canbas, T. Cabaroglu, H. Erten, J. P. Lepoutre, Z. Gunata, Aroma components of cv. Muscat of Bornova wines and influence of skin contact treatment, Food Control, 17 (2006) 75-82.

\section{Izvod \\ EFEKTI TRAJANJA HLADNE MACERACIJE NA SASTAV I SENZORNA SVOJSTVA VINA SMEDEREVKA}

Sonja N. Jordeva ${ }^{1}$, Kiro D. Mojsov ${ }^{1}$, Darko Andronikov ${ }^{1}$, Aco Janevski ${ }^{1}$, Stevan Gaber ${ }^{2}$

\footnotetext{
${ }^{1}$ Tehnološko-tehnički fakultet, Univerzitet “Goce Delčev” Štip, Republika Makedonija
}

2Ekonomski fakultet, Univerzitet “Goce Delčev” Štip, Republika Makedonija

lako sastav grožđa zavisi od sorte, tla i klimatskih uslova, postoji malo varijacija u stvarnoj strukturi ćelije biljke. Kontrolisanje maceracije ili uslova dodira sa kožom je od vitalnog značaja za dobijanje kvalitetnih belih vina. U praksi se obično koristi klasična maceracija na temperaturi od $20-25^{\circ} \mathrm{C}$ i hladna maceracija na temperaturi od $5-10^{\circ} \mathrm{C}$. Cilj ovog rada je bio da se ispitaju promene u sastavu i senzornim svojstvima vina Smederevke dobijenih sa različitim trajanjem hladnog dodira sa kožom na $8{ }^{\circ} \mathrm{C}$ tokom 12 i 24 časova. Hemijska analiza vina sadrži osnovna hemijska jedinjenja, organske kiseline, ukupne fenole i više alkohole. Izvršena je senzorna analiza vina metodom 100 bodova. Rezultati su pokazali značajno povećanje suvog ekstrakta, pepela i ukupne fenole i smanjenje vinske kiseline i veći sadržaj alkohola u vina Smederevke dobijenih tokom $12 \mathrm{~h}$ ili $24 \mathrm{~h}$ hladne maceracije. Ovi rezultati ukazuju na to da hladna maceracija pozitivno utiče na kvalitet Smederevkih vina. Najbolji organoleptički kvalitet vina Smederevke je dobijen hladnom maceracijom na $8{ }^{\circ} \mathrm{C}$ tokom $24 \mathrm{~h}$.
(ORIGINALNI NAUČNI RAD) UDK 663.2:66.063.4

Ključne reči: vino, Smederevka, hladna maceracija, senzorna svojstva, ukupni fenoli. 